\title{
The Effect of Guided Inquiry Laboratory Activity with Video Embedded on Students' Understanding and Motivation in Learning Light and Optics
}

\author{
Tina Afriani1, Rika Rafikah Agustin¹, Eliyawati ${ }^{*}$ \\ ${ }^{1}$ International Program on Science Education, Faculty of Mathematics and Science Education, Universitas Pendidikan Indonesia, \\ Bandung, Indonesia \\ *Corresponding Author. eliyawati@,upi.edu
}

\begin{abstract}
This research aims to investigate the effect of guided inquiry laboratory activity with video embedded on students' understanding and students' motivation in learning lights and optics topic. The method used in this research was pre-experiment. The sampling technique used in this research was convenience sampling, and the samples were taken from grade 8 in one of junior high school in Bandung. The sample was 20 students. The class implemented guided inquiry laboratory activity with video embedded in learning light and optics. The students' understanding was measured using test given at pretest and post-test while students' motivation was calculated using software ministeps (RASCH Model). The t-test paired sample also was performed on the average level of $95 \%$ to identify the significant difference of students' understanding before and after the implementation of guided inquiry laboratory activity with video embedded. The results of this research show that the use of guided inquiry laboratory with video integrated gives an improvement of students understanding. Even though the value of n-gain is 0,264 (categorized as low level), the statistical test shows that there is a significant difference between students understanding before and after the implementation of guided inquiry laboratory activity with video embedded. There are 15 students from 20 students who are motivated in learning light and optics by using guided inquiry laboratory activity with video embedded. Students are motivated by the implementation of guided inquiry laboratory activity with video embedded.
\end{abstract}

Keywords Guided inquiry laboratory activity, Video embedded, Students' understanding, Students' motivation, Light, and optics

\section{INTRODUCTION}

Physics is a branch of science that studies about natural phenomena that are physically by observation, experiment, and theory. Physics is taught through learning activities in schools by a set of activities that are designed to support student learning (Prima, Utari, Chandra, Hasanah, \& Rusdiana 2018). The principle of learning physics is to prioritize scientific processes to produce products and to be based on scientific attitudes. The scientific process in learning physics is identical to the implementation of activity with the scientific method (Sari \& Sunarno, 2018). There are lots of learning models, approach, and learning methods that can support the process of learning physics. Based on the 2013 curriculum of Indonesia, current science learning need to use a scientific approach. Scientific learning is learning that adopts scientific steps in building knowledge through the scientific method (Puspitasari, Lesmono, \& Prihandono, 2015). In line with curriculum 2013, teachers must have learning support devices in the form of teaching materials, worksheets, discussion sheets, and media used to facilitate students in understanding the material (Sunarya, \& Mudzakir, 2017; Prima, Putri, \& Sudargo, 2017).

Students' learning outcomes for physics subjects are relatively still low. When learning physics, it is found that the lack of seriousness of most students in learning physics is that students do not play an active role in the class and still focus to teacher center (Sari \& Sunarno, 2018). Most students' do not have right learning motivation and a positive attitude in learning physics (Prima, Putri, \& Rustaman, 2018). This indicated by the lack of the seriousness of students' in learning physics and the negligence of students' to do assignments from the teacher. In addition, there are several factors that affect students' learning result; which are in the instrument, learning device such as curriculum, program structure, learning facilities and learning media, and teachers as learning designers.

Received: 27 January 2019

Revised: 28 May 2019

Published: 22 July 2019 
There are several ways to support the physics learning process is using media is one kind of innovative learning. By watching the video, students' emotions are triggered by specific visual scenes, the actors, and background music. A video can have a substantial effect on students' mind (Berk, 2009). Video is a combination of images and sound, create a powerful medium for an explanation of concepts while instructing learners with content that provides multiple senses (Pratiwi, Rochintaniawati, \& Agustin, 2018).

Laboratory activity is significant in learning science. The purpose of laboratory work is to developing students understanding related to scientific content, problemsolving skill, and science processes skills. Students have to know the connection between experiment and scientific theory. By scientific inquiry, students determine the problems, developing solutions, and alternative solutions for these problems, search for information, evaluate the information, and communicate with their friends (Salsabila, Wijaya, \& Winarno, 2018).

Learning with guided inquiry is an effective way to vary the atmosphere of classroom teaching patterns. Guided inquiry learning is group learning where students are given the opportunity to think independently and help each other with friends and guide students to have individual responsibilities and responsibilities in groups or partners (Ambarsari, Santosa, \& Maridi, 2013).

In guided inquiry laboratory activity, student search for an experiment by the given problem. Usually, Guided Inquiry experiments are based on discovery, the procedure is predetermined (Kumdang, Kijkuakul, \& Chaiyasith 2018). The use of Guided Inquiry laboratory activity, in which students have principal autonomy in the design and execute the experiment (Fakayode, 2014). Teachers should move away from traditional lecturing and cookbook-style laboratories to active learning strategies that help students to develop their cognitive processes (Tessier \& Penniman, 2006).

In the guided inquiry laboratory method, student search for an experiment by a given problem. In this activity, the experiments are similar to the expository experiments, but a lab manual is not given to the students. Students search for the experiment process and reach scientific information by the test (Ural, 2016a). Guided inquiry laboratory enhanced students' learning.

Using video have an advantage which is can help students to observe the phenomena that too fast or too long happened. The use of animation video can attract students to more focus on the explanation of the concept and can saving time in explaining the concept. Learning with video animation can give the opportunity to student and teacher to teaching and learning faster and combine active learning and technology.

The characteristic of the video is in the form of animation with colorful and cheerful visual and audio, the source of the video is from YouTube. There is a YouTube channel named Peek a boo that contains some educative video for any subject, peek a boo make a character that is used to explain the material named dr. Binocs with the title of the video is The dr. Binocs Show.

In this research, the topic of Light and Optics is chosen because based on the information from the student learning method that is used in the class still teacher center. The teacher only delivers the concept based on the handbook, and then students were asked to answer the questions from the book. And also still lack laboratory activity in learning light and optics, the teacher even uses lecturing method to delivers the concept. Students are too difficult to focus and pay attention to the teacher during teaching-learning activity. It caused students learning outcome are low.

Previously, there are several research conducted to improve students' understanding in light and optics topic by implementing several approach, method or models, such as Virtual Laboratory Flash Animation (Permana, Widiyatmoko, \& Taufiq, 2016), interactive module with LCDS program by Arbai, Edie, and Pamelasari (2014) and using Direct Instruction Model by Anggraini, Zainuddin, and Miriam (2017). However, there is no research about guided inquiry laboratory activity with video embedded in learning Light and Optics. Such research could further suggest changes in educational practices. For this reason, this research was initiated to investigate students' understanding and motivation by using Video embedded guided inquiry laboratory activity among $8^{\text {th }}$ Grade students. It is thought that by using guided inquiry laboratory activity with video embedded will increase students' understanding of light and optics topics and motivate students' in learning light and optic.

Such research could further suggest changes in educational practices. For this reason, this research was initiated to investigate students' understanding and motivation by using guided inquiry laboratory activity with video embedded among $8^{\text {th }}$ Grade students. It is thought that by using guided inquiry laboratory activity with video embedded will increase students' understanding of light and optics topics and students' motivations and students' understanding of learning light and optic.

\section{METHOD}

The research method that was used in this research was pre-experiment. Pre-experiment a type of research that uses a single subject to determine the causal relationship between the independent variable and dependent variable without any extraneous variable (Anderson, \& Krathwohl, 2001). This method is appropriate with the purpose of this research that investigates the effect of Guided Inquiry Laboratory Activity with Video embedded on students' understanding and motivation in learning light and optics. It can determine the change of independent variable but not due to extraneous factors. The pre-experimental 
Table 1 Research design of one group pre-test and post-test

\begin{tabular}{lll}
\hline Pre-test & Treatment & Post-test \\
\hline $\mathrm{O}_{1}$ & $\mathrm{X}$ & $\mathrm{O}_{2}$ \\
\hline
\end{tabular}

Table 2 Descriptive statistic of objective test, pre-test and posttest

\begin{tabular}{lll}
\hline Component & Pre-test & Post-test \\
\hline $\mathrm{N}$ & 20 & 20 \\
Average Score & 37,25 & 53,25 \\
Maximum Score & 55 & 75 \\
Minimum Score & 20 & 20 \\
& Normality & \\
Significant (sig & 0,134 & 0,472 \\
$\alpha=0,05)$ & Normally & Normally \\
Information & distributed & distributed \\
& Homogeneity & \\
Significant (sig & 0,032 & \\
$\alpha=0,05)$ & The data are Homogen \\
Information & & \\
Significant (sig & Hypothesis Test \\
$\alpha=0,05)$ & H1 accepted, there is a significant \\
Information & difference \\
\hline
\end{tabular}

method may able to approach the true experimental process (Cohen, Manion \& Morrison, 2007).

The research design that was used in this research was one group pre-test and post-test as seen in Table 1, which means that the researcher only takes an experimental group to measures the groups' dependent variable (O1), that usually called as a pre-test. The pre-test was given to the subject using an instrument in the form of multiple choices. The next step was giving an experimental manipulation $(\mathrm{X})$, by learning with Video embedded with Guided Inquiry Laboratory Activity, before conducting post-test.

The research was taken in private Junior High School in Bandung. The school uses Bahasa Indonesia in their learning activity of Science. The curriculum of the Junior High School is National Curriculum of 2013.

The population in this research was $8^{\text {th }}$-grade students' of the public Junior High school in Bandung. The samples were $8^{\text {th }}$-grade students from one class consist of 20 students. Consist of 12 male and 8 female with age around 14 years old. The sampling technique that was used was convenience sampling, which is a selection of the subjects that selected by the willingness of the researcher and its available to be studied (Cohen, Manion, \& Morrison, 2007).

The objective test was developed to measure students' understanding of Light and Optics. This test was given to the students in pre-test that was before any implementation of Guided Inquiry Laboratory with Video Embedded, and post-test that was after the treatment given the students. The purpose of post-test was given to measure students' understanding after the treatment.

The type of question that was given in the pre-test and post-test are multiple-choice, contained 25 questions. All test items were judged by the experts and tested to the students' that have learned about light and optics.

To determine students' motivation in learning light and optics with Video Embedded with Guided Inquiry Laboratory Activity that is used in this research, a questionnaire is developed by using 4 point Likert-scale (Strongly agree, agree, disagree, strongly disagree). The Students' Motivation Toward Science Learning (SMTSL) was used to assess students' motivation in learning light and optics and the students' answer was to analyze by statistical software, namely RASCH model.

\section{RESULT AND DISCUSSION}

\subsection{The effect of Guided Inquiry Laboratory Activity with Video Embedded on students understanding in learning light and optics}

The objective test was given to the subject of the research to determine their understanding. The instrument was distributed twice, pre-test and post-test, the concept that was used are the same, which is Light and Optics. Moreover, the score that has been obtained from all research subjects were analyzed to determine the normality of items, homogeneity test of items, also hypothesis of the research. The SPSS software was used to analyze the data that consist of 25 questions in the form of multiple choices.

Table 2 shows that the average score of post-test is higher than the pre-test. From 20 students in the pre-test, the maximum score is 55. It is proving that the students' prior knowledge is still low. In this research, the average is too low to be categorized as a good score in line with the minimum criteria of mastery learning in the school, which is 65 . There only three students who get score 50 . The other scores are below 50; even the worst is 20. Meanwhile, after the implementation of learning using the Guided Inquiry Laboratory with Video Embedded, the maximum rating is 75 .

The post-test score is higher than pre-test, it is because after the post-test and re-check their answer most students can answer the questions that they cannot respond in the pre-test. This is because during teaching-learning activity students more active and more explore their activity. Some students relish learning with guided inquiry laboratory activity with video embedded, it makes students easier to absorb new knowledge. It is because guided inquiry laboratory activity with video embedded improves students understanding about light and optics by involving students in a scientific atmosphere where they are allowed to try how a scientist works. During the teaching-learning process with guided inquiry laboratory activity, they are stimulated to pose scientific questions, collect and analyze the data from hypothesis, design and conduct a scientific investigation, formulate the explanation and communicate the arguments.

The normality test result of pretest and posttest shows that the data are typically distributed because the result 
shows the values which are more than 0,05 . The method of calculating normality using Shapiro-Wilk because the sample is only 20 , which was a small number and this method is effective to reduce the error of normality in a few amounts (Cohen, Manion, \& Morrison, 2007). The improvement of students understanding can be indicated by the average gain score which is 16.00 . The average normalized gain score is 0.264 . It means that the average normalized gain score is at a medium level. The same with the normality test result, the homogeneity test result of pretest and posttest shows a value which is more than 0,05 , it can be said that the data is homogeny.

Because the data were normal and homogeny, than it decided to compare the mean used parametric statistics which was Paired Sample T-Test. Obtained that the sig. value 2 -tailed of T-test paired sample is 0.000 . Compared to the significance $(\boldsymbol{\alpha})$, which has the value 0.05 , the sig. amount 2 -tailed is smaller than the significance $(\boldsymbol{\alpha})$ value. Then it can be concluded that $\mathrm{H}_{1}$ is accepted, which means that there is a significant difference in students understanding between pre-test and post-test using Guided Inquiry Laboratory with Video Embedded in Learning Light and Optics.

In line with the other research about guided inquiry, the students in the guided-inquiry condition demonstrated significant improvements in both conceptual understanding and their levels of explaining the concept (Ambarsari, Santosa, \& Maridi, 2016). The result of implementing guided inquiry shows that there has been a significant increase in students' attitudes, and their academic achievement (Ural, 2016b).

\subsection{Students' Motivation in Learning Light and Optics}

Students' Motivation in Learning Light and Optics, in this research, determined using questionnaire using 4 Likert scale. In the questionnaire only use a 4-Likert scale because the neutral option is meaningless, a neutral option does not express whether it positive or negative opinion. The neutral option was excluded as a strategy to encourage students to express either a positive or negative opinion, rather than remaining neutral. The questionnaire was given to research subject after conducting post-test. The overview of this questionnaire is the motivation of students in learning science using Guided Inquiry Laboratory with Video Embedded, especially in learning Light and Optics topic. The RACSH model was used to analyze the instrument that consists of 25 statements in the form of the questionnaire. The neutral option was excluded as a strategy to encourage students to express either a positive or negative opinion, rather than remaining neutral. The questionnaire was given to research subject after conducting post-test. The overview of this questionnaire is the motivation of students in learning science using Guided Inquiry Laboratory with Video Embedded, especially in learning Light and Optics topic.
After the questionnaire was given to the subject, then the score that has been obtained were analyzed used ministep software from RACSH model to determine the profile of students motivation in learning light and optics. The RACSH model was used to analyze the instrument that consists of 25 statements in the form of a questionnaire as shown in Figure 1. The result shown in the form of Variable maps, there is two areas in the maps which is person area and item area. Person map indicates students meanwhile item indicates the students' motivation statements. This variable map arranges the students from the students who have high motivation for the students who have low motivation in learning Light and Optics (topbottom). The top item indicates the hardest students' motivation statement to approve and the bottom item indicates the easiest students' motivation statement to approve.

From the data 09L is the person who stands higher in the top than other people, that means the person with code 09L is the most person that approves with the statement in the questionnaire or $09 \mathrm{~L}$ is the most motivated students that other subject of the research. In the result, person 09L can answer all the states in the survey even the hardest statement to be approved. Then, there was 19L that stand in the bottom than other people, that is mean the person $19 \mathrm{~L}$ is the hardest to agree with the statements in the questionnaire or 19L is the less motivated students after the treatment.

The data shows there were 15 persons that more motivated than the other person, 15 persons consisted of 9 male and 6 female. And there were 2 persons that less motivated that consist of 1 male and 1 female. Based on the limits of the data above, there are 3 students whose

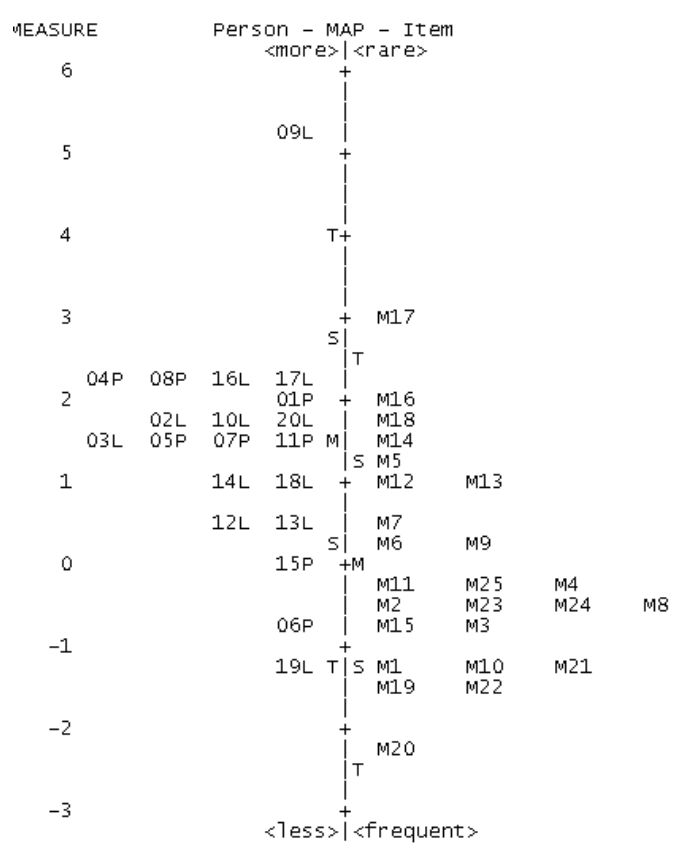

Figure 1 The result of students' motivation 
learning motivation is so-so. That consists of 2 male and 1 female.

On the data not only person who more motivated or less motivated, but there also obtained data about the item motivation that easiest to approve and the item motivation that hardest to approve. Based on the data shows that there was an item that hardest to approve that is M17 or item number 17, which states "I participated in learning light and optics so I would look smarter than other students". There also shows an item that easiest to approve that is M20 or item number 20, which is a state "I feel delighted when I can solve complex problems". Based on the data persons 04P, 08p, 16L, $17 \mathrm{~L}$, and 01P cannot approve the statement M17 or item number 17 as stated above. Then, persons $02 \mathrm{~L}, 101$, and $20 \mathrm{~L}$ cannot agree with statement M17 and M16, but they approve statement M18 and the rest of the statements.

Next are persons 03L, 05L, 07P, and 11P they cannot approve M17, M16, and M18 but they can approve M14 and the rest statement. Contrast with 10L, 03L, 05L, 07P, and $11 \mathrm{P}$ recommend statement M14 that has been stated above, it may indicate they prefer to ask the answer to other as an easy way to answer the assignment rather than they think and find the answer by themselves. Then, persons 14L and 18L cannot approve statement M17, M16, M18, M14, and M5 but they agree statement M12 and M13 and the rest of statements. M5 stated "I want to take part in learning light and optics because it is exciting", they did not approve the statement may indicate learning light and optics cannot attract their interest or they not attract in learning physics.

Persons 12L and 13L only approve M7 and the rest of the statements and cannot approve M12 and M13, M12 stated "I believe I can do test in chapter light and optics" and M13 "If there is assignment in light and optic that have difficult part, I will pass it and try the easiest one". It may indicate a lack of confidence in answering questions from the test or assignment.

Statement M7, M6, and M9 cannot be approved by person 15P, M6 stated "When I was learning a new concept in chapter light and optics I relate the concept with my experiences" and M9 "During learning light and optics I try to relate every concept I've learned before." But person $15 \mathrm{P}$ can approve the rest of statements, this may indicate person 15P lack of previous mastering concept. Person 06L cannot approve statement M11, M25, M4, M2, M23, M24, and M8, but 06L can approve M15 and M3. M15 stated, "I participated in learning light and optics to get good scores" and M3, "I think it is important to learn how to solve the problem in chapter light and optics." It may indicate, a person during the teaching-learning process $06 \mathrm{~L}$ try to learn how to solve a problem in chapter light and optics to get a good score in the final test.

Not an only variable map, there also scalogram as the result of data analyzed using RASCH model. Scalogram

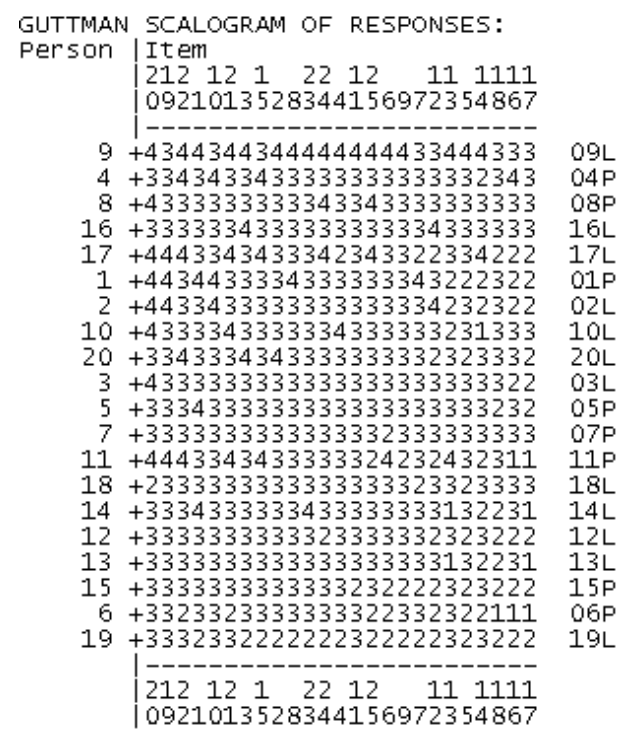

Figure 2 Scalogram showing the response pattern systematic between students' motivation (sorted from high to low ability vertically, top to bottom) and items' motivation (classified from manageable to severe horizontally, from left to right)

shows the response pattern systematic between students' motivation (sorted from high to low ability vertically, top to bottom) and items' motivation (classified from manageable to severe horizontally, from left to right) as seen in Figure 2. Both scalogram and variable maps. The students who have high motivation is $09 \mathrm{~L}$, and the students who have low motivation is $19 \mathrm{~L}$.

There are a number of students who have unique response patterns. Some students have unique patterns such as 17L, 18L, 06P, and 19L. Students with 17L code, on motivation item 4 answered disagree even though for the following items that had a higher difficulty level (more difficult to agree), he actually answered strongly agree. Likewise, students with code 06P, inconsistent because on motivation items 21 and 22 answered no agree, even though there should be a pattern and showing from variable maps that $06 \mathrm{P}$ must answer agree. The last unique thing that can be analyzed is that students with the $19 \mathrm{~L}$ code where students are less motivated can be seen from the answers, which most patterns disagree with the statement of motivation in learning light and optics.

From the data, it was obtained that guided inquiry laboratory activity with video embedded in learning Light and Optics can motivate students. The improvement of students motivation with guided inquiry laboratory activity can happen because students feel challenged or new things to find the concept by the experiment, then students look enthusiastic and interested during the teaching-learning process. Learning with guided inquiry laboratory activity can make learning activity more meaningful for students because the experience that they get from the experiment activity can help students to relate and explain the event that connects with daily life. The experiment that was 
conducted to get the data can increase students selfconfidence. Discussion activity that was conducted after the experiment activity can make students more confident for the asking and deliver their opinion. This is in line with previous research, teaching using guided inquiry can increase students motivation in learning science (Yuniastuti, 2013). Science laboratories in schools support and promote student motivation and learning strategy use (Milner, Templin, \& Czerniak, 2011).

\section{CONCLUSION}

Be rooted in data analysis, the use of guided inquiry laboratory activity with video embedded gives an improvement of students understanding. Even though the value of $\mathrm{n}$-gain categorized as low level, the statistical test shows that there is a significant difference between students' knowledge before and after the implementation of guided inquiry laboratory activity with video embedded.

Students are motivated by the implementation of guided inquiry laboratory activity with video embedded in learning light and optics. There are 15 students from 20 students who are motivated in learning light and optics by using guided inquiry laboratory activity with video embedded. Almost all statements related to students motivation toward science learning can be approved by students.

\section{ACKNOWLEDGMENT}

Author's wishing to acknowledge the principal of the school for the permission to conduct the research (teaching in the class for several meetings).

\section{REFERENCES}

Anderson, L. W. \& Krathwohl, D. (2001). Taxonomy for Learning, Teaching, and Assessing: A Revision of Bloom's Taxonomy of Educational Objectives. New York, NY: Longman

Almuntasheri, S., Gillies, R. M., \& Wright, T. (2016). The Effectiveness of a Guided Inquiry-Based, Teachers' Professional Development Programme on Saudi Students' Understanding of Density. Science Education International, 27(1), 16-39.

Ambarsari, W., Santosa, S., \& Maridi, M. (2013). Penerapan pembelajaran inkuiri terbimbing terhadap keterampilan proses sains dasar pada pelajaran biologi siswa kelas VIII SMP Negeri 7 Surakarta. Pendidikan Biologi, 5(1).

Anggraini, A. N., Zainuddin, \& Miriam, S. (2017). Meningkatkan Keterampilan Prosedural Siwa Melalui Model Pengajaran Langsung Pada Materi Ajar Cahaya Dan Alat-Alat Optik Kelas VIII F SMPN 26 Banjarmasin. Berkala Ilmiah Pendidikan Fisika, 1(3), 154-168.

Arbai, S. Z., Edie, S. S., \& Pamelasari, S. D. (2014). Pengembangan Modul IPA Terpadu Bermuatan Mind Mapping pada Tema Cahaya dan Penglihatan untuk Kelas VIII SMP/MTS. Unnes Science Education Journal, 3(1).

Berk, R. A. (2009). Multimedia teaching with video clips: TV, movies, YouTube, and $\mathrm{mtvU}$ in the college classroom. International Journal of Technology in Teaching \& Learning, 5(1).

Cohen, L., Manion, L., and Morrison, K. (2007). Research Method in Edcuation Sixth Edition. USA: Routledge.
Fakayode, S. O. (2014). Guided-inquiry laboratory experiments in the analytical chemistry laboratory curriculum. Analytical and Bioanalytical Chemistry, 406(5), 1267-1271.

Kumdang, P., Kijkuakul, S., \& Chaiyasith, W. C. (2018). An Action Research on Enhancing Grade 10 Student Creative Thinking Skills using Argument-driven Inquiry Model in the Topic of Chemical Environment. Journal of Science Learning, 2(1), 9-13.

Milner, A. R., Templin, M. A., \& Czerniak, C. M. (2011). Elementary Science Students' Motivation and Learning Strategy Use: Constructivist Classroom Contextual Factors in a Life Science Laboratory and a Traditional Classroom. Journal of Science Teacher Education, 22(2), 151-170.

Permana, N. A., Widiyatmoko, A., \& Taufiq, M. (2016). Pengaruh virtual laboratory berbasis flash animation terhadap pemahaman konsep dan keterampilan berpikir kritis peserta didik tema optik kelas VIII SMP. Unnes Science Education Journal, 5(3).

Pratiwi, W. N. W., Rochintaniawati, D., \& Agustin, R. R. (2018). The Effect of Multiple Intelligence-Based Learning Towards Students' Concept Mastery and Interest in Matter. Journal of Science Learning, 1(2), 49-52.

Prima, E. C., Putri, A. R., \& Rustaman, N. (2018). Learning Solar System Using PhET Simulation to Improve Students' Understanding and Motivation. Journal of Science Learning, 1(2), 60-70.

Prima, E. C., Putri, C. L., \& Sudargo, F. (2017). Applying Pre and Post Role-Plays supported by Stellarium Virtual Observatory to Improve Students' Understanding on Learning Solar System. Journal of Science Learning, 1(1), 1-7.

Prima, E. C., Utari, S., Chandra, D. T., Hasanah, L., \& Rusdiana, D. (2018). Heat and temperature experiment designs to support students' conception on nature of science. JOTSE: Journal of technology and science education, 8(4), 453-472.

Puspitasari, R., Lesmono, A. D., \& Prihandono, T. (2015). Pengaruh Model Pembelajaran Poe (Prediction , Observation and Explanation) Disertai Media Audiovisual Terhadap Keterampilan Kerja Ilmiah Dan Hasil Belajar Siswa Dalam Pembelajaran IpaFisika Di Smp. Jurnal Pembelajaran Fisika, 4(3), 211-218.

Salsabila, E. R., Wijaya, A. F. C., \& Winarno, N. (2018). Improving Students' Sustainability Awareness through Argument-driven Inquiry. Journal of Science Learning, 2(2), 58-64.

Sari, N., Sunarno, W., \& Sarwanto, S. (2018). Analisis Motivasi Belajar Siswa dalam Pembelajaran Fisika Sekolah Menengah Atas. Jurnal Pendidikan dan Kebudayaan, 3(1), 17-32.

Schoffstall, A. M., \& Gaddis, B. A. (2007). Incorporating guided-inquiry learning into the organic chemistry laboratory. Journal of Chemical Education, 84(5), 848.

Sunarya, Y., \& Mudzakir, A. (2017). Solar Cell as Learning Multimedia to Improve Students' Scientific Literacy on Science and Nanotechnology. Journal of Science Learning, 1(1), 36-43.

Tessier, J. T., \& Penniman, C. A. (2006). An inquiry-based laboratory design for microbial ecology. Bioscene, 32(4), 6-11.

Ural, E. (2016a). The Effect of Guided-Inquiry Laboratory Experiments on Science Education Students' Chemistry Laboratory Attitudes, Anxiety and Achievement. Journal of Education and Training Studies, 4(4), 217-227.

Ural, E. (2016b). The Effect of Guided-Inquiry Laboratory Experiments on Science Education Students ' Chemistry Laboratory Attitudes, Anxiety and Achievement, 4(4), 217-227.

Van Zile-Tamsen, C. (2017). Using Rasch analysis to inform rating scale development. Research in Higher Education, 58(8), 922-933.

Yuniastuti, E. (2013). Peningkatan keterampilan proses, motivasi, dan hasil belajar biologi dengan strategi pembelajaran inkuiri terbimbing pada siswa kelas VII SMP Kartika V-1 Balikpapan. Jurnal penelitian pendidikan, 13(1). 